\title{
Factors Affecting The Performance Fea Coordinating The Family Planning National Makassar
}

\author{
HJ. Nuraeni \\ Institute of Economic Science Wirabakti Makassar
}

\begin{abstract}
Factors Influencing Performance Against Power Extension of the National Family plann ing Coordinating Board Makassar. The purpose of this study was to Determine the Factors Influencing Performance Against Power Extension of the National Family Planning Coordinating Board Makassar. The population in this study is the Power Extension of the National Family Planning Coordinating Board Makassar with a sample size of 90 people. Data collection methods in this study were questionnaires, interviews, and documentation. Methods of analysis of data using descriptive method and quantitative method with multiple linear regression analysis were used to measure the Influence of Education and Training, Motivation and Incentive Performance Against Power Extension of the National Family Planning Coordinating Board Makassar. Based on F test of independent variables (education and training, motivation and incentives) jointly have the positive and significant influence on the dependent variable (performance FEA). Through testing the correlation coefficient $(R)$ was Obtained that level of correlation or relationship between education and training, motivation and incentives to the performance of extension workers is a high correlation is equal to 78.1 percent. While the remaining $21.9 \%$ is influenced by other factors. And Incentives is the most dominant performance factor Influencing Extension Workers National Family Planning Coordinating Board Makassar.
\end{abstract}

Keywords: education and training, motivation, incentives and performance

\section{Preliminary}

HR within the organization acting as executor component work and also as a partner that determines the development of the organization. HR qualification is crucial image, confidence and quality of services that directly affect the performance level which then determines the level of participation to the successful achievement of the goals anisasi org.

Personal performance within the organization can be improved through a variety of efforts made by the organization itself as well as business and personal as a person. Improved performance is a requirement of every personal support of the goals to be achieved by a personal organization. Human resources as well as a reliable and high performance will be achieved if constantly improve employees through various efforts so that the services provided will be more efficient and effective.

Realizing that potential and ability of family planning counselors uneven then it is necessary to formulate the direction and discretion of agricultural development in the framework of national development are implemented through family planning educator empowerment strategy towards more advanced, independent, prosperous, and equitable. The development of family planning future extension is expected to make a greater contribution in order to reduce the gap and expanding employment opportunities, and be able to take advantage of all the opportunities that occur as a result of globalization. The question now is the extent to which improved performance extension of family planning as a human resources can be achieved, and how the organizational strategy in anticipation of changes in the relevant conditions to be applied in order to improve the work quality of human resources in order to achieve productivity extension of family planning is high so as to achieve a level adap terh efficiency and effectiveness of all stakeholders.

According to data obtained from the National Family Planning Coordinating Board (BKKBN) Makassar city on Family Planning Extension performance tends to decline, marked by the emergence of several cases below:

1. Total extension of family planning 105 people spread in 14 subdistricts in Jeneponto only about $50 \%$ were found active in the Work Area Illumination pad a family planning during working hours / time of the visit.

2. Depositing work plan extension family planning inconsistent. Supposedly in January each year is already full is received by the Head of Division of the National Family Planning Coordinating Board (BKKBN) Makassar City but in fact only 13 people were put up in 2014.

3. Attendance counselor family planning regular meetings each month tends to decrease. In accordance with an average attendance are present only $20 \mathrm{~s} / \mathrm{d} 30$ people so what is the problem in the field are rarely monitored accurately. ,

In this regard, there should be efforts to increase energy performance Extension Family Planning (PKB) on a continuous basis. PKB high energy performance, usually characterized by the ability to work and work motivation tall one. Therefore, it is necessary to investigate the significant Factors Influencing 
Performance Against Power Extension of the National Family Planning Coordinating Board Makassar, so that later can be used as a material consideration in setting policies to improve the power performance $\mathrm{P}$ enyuluh $\mathrm{F}$ amily B erencana.

\section{K Ajian Literature}

Human Resources is one asset (wealth) which the company plays an important role in achieving the objectives of the company / organization. Armstrong (2009: 4) states that the practice of human resource management (HRM) in relation to all aspects of how people work and are managed within the organization. This includes activities such as HR strategy, HR management, corporate social responsibility, knowledge management, organizational development, sources of HR (human resource planning, recruitment and selection, and talent management), performance management, learning and development, management remuneration, employee relations, employee welfare, health and safety, as well as the provision of employee services. HR practices have a strong conceptual basis, drawn from the behavioral sciences and of strategic management, human capital, and not through Home Visits industrial relations theory.

Performance is the result of the work or the work produced by each employee to assist enterprises in achieving and realizing the objectives of the enterprise. Basically, the performance of a person is individualized for each of the employees have different levels of ability. Employee performance is more directed at the level of employee job performance.

Performance According to Gomes et al., (2001: 243) is a condition that must be known and informed of certain parties to determine the level of achievement of an organization linked to the vision and mission assigned to an organization and mengetahuidampak positive and negative on operational policies that been predetermined. Performance management is used to perform periodic penelian on the effectiveness of employees based on their duties and functions (TUPOKSI) and based on predetermined standards. Performance (performance) both individual and organization can be used as a means of controlling (cotrolling) to the organization's success.

Training can be considered as activities to empower employees to be able to have the expertise and capability in performing their duties. The training process is to add insight, growing love, and to train communication skills through dialogue and contain elements of similarity which is expected to lead to motivation, requires a certain teaching methods of teachers. The training method can take the form of lectures, demonstrations, and discussions which aims to provide an understanding of knowledge, understanding and comprehension application analysis, synthesis s erta evaluation (Shah, 2002: 202).

Employees are human resources for national development has a strategic role, both in the organization of the life of the country and in order to smooth and successful development. Employee development efforts is necessary, that is through provision of opportunity for employees to participate in various educational and training courses, both technically functional as well as structural and formal academic education, both undergraduate $(\mathrm{S} 1)$ and postgraduate $(\mathrm{S} 2)$.

Motivation is "giving urges individuals to act that causes people to behave in a certain way which leads to the goal" (Ivan Aries and I mam Ghozali, 2006: 126). Pem b e rian motivation is one goal of keeping employees motivated to work according to reference work and responsibilities given so that the goal can be achieved with good company. Moreover, it also contained elements Unur efforts, the efforts of qualified and directed as well as consistent with the organization's objectives to be achieved.

Expectancy theory that in ungakapkan by Greenberg (1999) Rival (2005) looked at motivation as a result of three types of beliefs of the individual, consisting of expectations of conviction that one's efforts will affect perfomance. Performance will be towards the Instrumentality, namely barupa belief that someone good performance will be given remuneration in kind. Individuals, consisting of expectations of conviction that one's efforts will affect the performance. Performance will be towards the Instrumentality, which formed the belief that someone good performance will be given remuneration in kind. Individuals will assess reward explicitly or implicitly that will form a pe rsepsi on reward itself.

A According to Gomes (1997) in Rival (2005) motivation involves individual factors that include the needs (needs), goals (goal), attitude (attitude) and capability (ability), while classified as organizational factors include payments salary (pay), job security (job security), relationships among employees (co-workers), supervision (supervisors), praise (praise), and the work itself (job itself).

Incentives as a means of motivation that encourage employees to work with an optimal capacity, which is intended as an extra income outside the salary or wages that have been determined. The incentive is intended to meet the needs of employees and their families. Term incentive system is generally used to describe plans for the payment of wages are linked directly or indirectly with the varying standards of employee performance or profitability of the organization.

Compensation and incentives have a very close relationship, which is a component of incentive compensation and both were very decisive in achieving the goals and objectives of the organization as a whole. 
Incentives can be formulated as an adequate remuneration to the employee whose performance exceeds the standards set. Incentives is a motivating factor for employees to work better so that employee performance can be improved.

To obtain a clearer understanding of the incentive, here are some management experts expressed understanding me ngenai incentives. According to Malay SP Hasibuan (2001: 117), points out: "Incentives Additional remuneration is granted to certain employees whose performance above standard achievement. This incentive is a tool used in the provision of supporting the principle of fair compensation ".

According to Anwar Prabu Mangkunegar a (2002: 89), suggests that "Incentives are a form of motivation that is expressed in the form of money on the basis of high performance and also a sense of recognition of the organization towards the employee's performance and contributions to the organization (company)."

Where in principle the provision of incentives for both parties. The company expects the strength or spirit that arise in the receiving incentives that encourage them to work better in the sense of more productive for the objectives to be achieved by the company / institution can be fulfilled while for employees as one means of satisfying their needs.

\section{Conceptual Framework}

The conceptual framework is a synthesis of the relationship between the variables drawn from the various theories that have been described (Sugiyono, 2008: 89). The conceptual framework aimed at addressing in general about the variables in this study is composed of the Education and Training as a variable $\left(\mathrm{X}_{1}\right)$, Motivation as a variable $\left(\mathrm{X}_{2)}\right.$, and Insenttif as a variable $\left(\mathrm{X}_{3)}\right.$ while the performance as a variable $(\mathrm{Y})$.

For more details of this conceptual framework are as follows:

Figure 1 Framework Kon perceptual Research

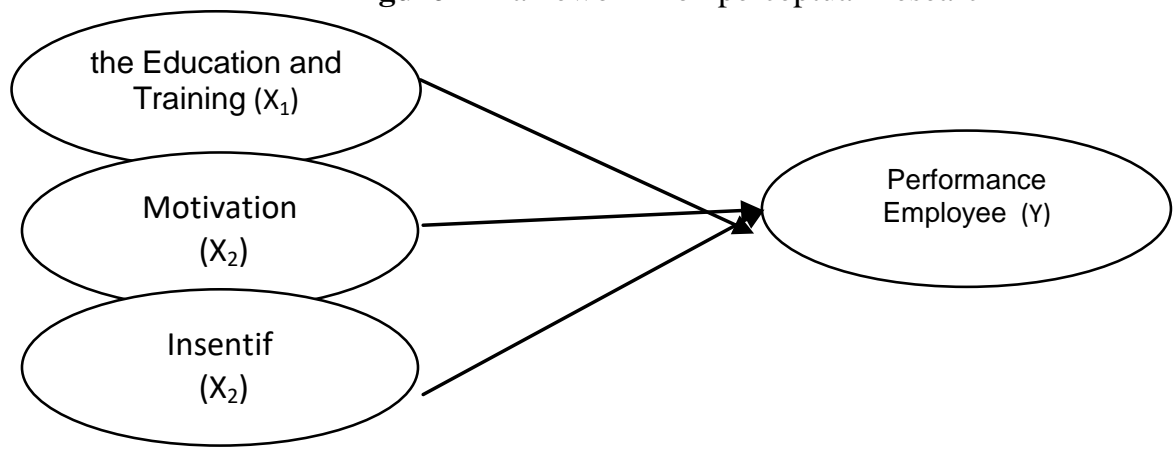

\section{B. Hypothesis}

Hypothesis is a temporary answer to the formulation of research problems (Sugiyono, 2008: 51). Hypothesis in this research is as follows:

1. Education and Training Factors have a positive and significant impact on the performance of employees at the Family Planning Extension staff in Makassar.

2. Motivation factors have a positive and significant impact on the performance of employees at the Family Planning Extension staff in Makassar.

3. Incentive factors have a positive and significant impact on the performance of employees at the Family Planning Extension staff in Makassar.

4. Incentive factor has a dominant effect on employee's performance in Family Planning Extension staff in Makassar City.

Types and Sources of Data

\section{Research Methods}

\section{Types of Data}

The data used in this study are primary data and secondary data, in the form of quantitative and qualitative. The quantitative data in the form of figures, scales, tables, formulas, and so on that a bit much use mathematics, whereas qualitative data in the form of data that can not be measured by numbers or other sizes that are exact.

\section{Data Sources}

The data source has a very important role in the study because of the presence of the author of the data source will receive resources that can be used to find all information relating to the research conducted. Source of data to support answers to the problems in research in the following manner: The primary data source: Namely data obtained from the first source, in this case the whole t enaga Extension Family Planning in Makassar. Secondary data source: Namely data obtained from the records, books, papers, reports, records and other documents. 


\section{Population and Sample}

The population is the sum of the entire object (units / individuals) whose characteristics are about to allegedly (Djarwanto, 1998: 107). The population in this study are Power Extension on Family Planning Office in Makassar amounted to 145 civil servants. The sample is part of the population that will be the object of the study sample in this study is Power Extension in Family Planning Office in Makassar. The sample size in the study was obtained by using the following formula (Slovin). So the sample in this study is the number 105 People Power Extension in Family Planning Office in Makassar.

\section{Analysis method}

The analytical method used to test the above hypothesis is Multiple regression with the equation:

$\mathrm{Y}=\mathrm{b}_{0}+\mathrm{b}_{1} \cdot \mathrm{X}_{1}+\mathrm{b}_{2}+\mathrm{b}_{3} \cdot \mathrm{X}_{2} \cdot \mathrm{X}_{3}+\mathrm{e}_{\mathrm{i}}$.

Where:

$\mathrm{Y}$ : Employee Performance

$\mathrm{X}_{1:}$ : Education \& Training

$\mathrm{X}_{2:}$ Motivation

$\mathrm{X}_{3} \quad$ : Incentives

$\mathrm{b}_{0} \quad$ Constants

$\mathrm{b}_{1,} \mathrm{~b}_{2,} \mathrm{~b}_{3:}$ The regression coefficient (parameter) is estimated

$\mathrm{e}_{\mathrm{i}} \quad$ Factor mistake (error)

The data used in this study consisted of primary and secondary data. Data Primary data is data obtained directly from the field through interviews or by using a questionnaire (questionnaire) and respondent (PNS employees at the District Office Mariso in Makassar).

$\mathrm{b}_{0 \text { : }}$ Constant / intercept

$\mathrm{b}_{1}-\mathrm{b}_{5}$ : regression coefficient / parameter

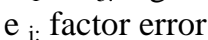

Furthermore, to determine the effect of the independent variables related variables, either jointly or individually used F-test, $\mathrm{t}$-test and the coefficient of determination $\left(\mathrm{R}^{2)}\right.$ and partially $\left(\mathrm{r}^{2)}\right.$

To test the hypothesis as follows:

1. Validity to show the extent of the measuring instrument mengukul thing to be measured, once calculated, the correlation value is obtained and compared with a critical number $r$ correlation table. If the correlation value obtained is larger than the value of $r$ criticism correlation table, then Ho is rejected and Ha accepted. Comparing the correlation number obtained with the correlation table critique numbers $r$ value. When the value of $r>r$ table, then the question is valid or significant in this study, the correlation table critique figure for the value of $r$ is $r(\mathrm{~N}-2 ; \alpha)$. Test Validity performed using SPSS 21 .

2. The reliability test is an index indicating the extent to which the gauges can be trusted or relied upon. Reliability testing technique used is by Cronbac. Cronbach technique used to find the instrument reliability scores range between values, eg, 0-10 or 0-1000 or form skal 1-3,1-5 or 1-7 and so on. According Singgih (2000), states that Croanbach Alpha coefficient is between 0 and 1. The closer the figure 1.0, the better the consistency of the instrument under test. Cronbach Alpha coefficients votes beradasrkan the following rules:

${ }_{\text {Alpha }} r>0.9=$ perfect $_{\text {Alpha }} r>0.8=$ good, ${ }_{\text {Alpha }} r>0.7=$ acceptable, $_{\text {Alpha }} r>0.6=$ questionable, ${ }_{\text {Alpha }} r>0.5=$ bad, ${ }_{\text {Alpha }} r<0,5=$ unacceptable. The reliability test menngunakan SPSS 21.

3. T test (partial) was used to test the parameters of the regression coefficient of each independent variable partially. This means that the $t$ test can determine whether the independent variables individually have a significant impact on the response variable.

Examiners are:

$\mathrm{H}_{\mathrm{o}}: \mathrm{b}_{\mathrm{i}}=0$ (factor $\mathrm{X}_{\mathrm{i}}$ is not influenced $\mathrm{Y}$ )

$\mathrm{H}_{\mathrm{i} ;} \mathrm{b}_{\mathrm{i}}=\mathrm{O}_{(\mathrm{i}} \mathrm{X}$ factor influencing $\mathrm{Y}$ ), if an $\mathrm{X}$ factor has an effect on $\mathrm{Y}$, if the value of ${ }_{\mathrm{t}}$ is greater $\mathrm{t}_{\text {table }}$ or calculated probability value is smaller than $\alpha(\alpha=5 \%)$. The influence here means that there is resistance to $\mathrm{H}_{\mathrm{o}}$. Sedagkan reverse if the $\mathrm{t}$ value is smaller $\mathrm{t}_{\text {table }}$ or a probability value is bigger than $\alpha(\alpha=5 \%)$, then menunujukkan factor $\mathrm{X}$ has no effect on $\mathrm{Y}$.

$t_{\text {count }} \mathrm{t}_{\text {table }}$ or $\mathrm{P}$ value $<\alpha$; Reject $\mathrm{H}_{\mathrm{o}}$

thitung $<\mathrm{t}_{\text {table }}$ or $\mathrm{P}$ value $>\alpha$; Accept $\mathrm{H}_{\text {o }}$

4. F test (simultaneous test) was used to test the suitability of the model simultaneously apaka $\mathrm{h}$ education and training, employee incentives motivas i and influence on employee performance. A factor $\mathrm{X}$ will affect $\mathrm{Y}$ is greater than $\mathrm{F}_{\text {table, }}$ then at least one $\mathrm{X}$ affects $\mathrm{Y}$. Whereas if $\mathrm{F}$ count is smaller than $\mathrm{F}_{\text {table, }}$ then none $\mathrm{X}$ dipastikantidak affecting $\mathrm{Y}$. If further elaborated:

Htiung $\mathrm{F}<\mathrm{F}_{\text {table }}$ then $\mathrm{H}_{\mathrm{o}}$ accepted, meaning that the $\mathrm{X}$ factor together did not significantly affect $\mathrm{Y}$. 
$\mathrm{F}_{\text {count }>} \mathrm{F}_{\text {table }}$ then $\mathrm{H}_{\mathrm{o}}$ rejected, meaning that at least one $\mathrm{X}$ factor that significantly affect $\mathrm{Y}$.

5. To see the close relationship anatar independent variable (Independent Variable) on the dependent variable (dependent variable) is explained by the correlation coefficient $(\mathrm{R})$ if the value of $\mathrm{R}>0.5$ means the relationship is strong, $\mathrm{R}=0.5$ means that the relationship was and $\mathrm{R}<0.5$ means the relationship is weak.

6. To estimate the percentage dependence dependent variable (dependent variable) and the constant interskep described by the coefficient of determination $\left(\mathrm{R}^{2)}\right.$ or $(R$-square $)$ and if influence Interskept issued then $\mathrm{R}^{2}$ to $\mathrm{R}^{2}$ correlated (Adj. R-Square). Rated $\mathrm{R}^{2}$ coefficient of determination that indicates how much the dependent variable changes caused by changes in the independent variables together.

\section{Operational definition}

Related variables (dependent variable) in this research is employee performance $(\mathrm{Y})$ and as vriabel free (independent variable) is education and training ( $\mathrm{x}_{1}$ ), motivation $\left(\mathrm{X}_{2)}\right.$ and incentives $\left(\mathrm{X}_{3}\right)$. Operational definitions ri $\mathrm{d}$ a $\mathrm{m}$ a sing- each study is the formulation of the problem and the proposed hypothesis, the variables that were analyzed can be identified as follows:

\section{Education \& Training as an independent variable $\left(\mathbf{X}_{1)}\right.$}

Gomes (2003: 89) education and training is any attempt to fix perfomansi worker to a particular job being its responsibility, or the work that has to do with job education and training can be measured by modifying the instrument developed by Aiben et.al in Fuad Mas' ud (2004: 128) using a scale of 5 levels of 1 liekrt strongly agree to strongly agree 5 . The indicators are:

1) Evaluation criteria

2) Preliminary tests (pratest)

3) Employees are trained or developed

4) Full test (post-test)

5) Transfer or promotion and follow-up.

Variable Motivation (X2)

Motivation is a boost in self employees who need to be met for these employees can solve the self to the environment ::

a. Continuous and rigorous oversight

b. Work atmosphere encourages morale

c. remuneration

d. Harmonious relations

e. Employees are treated objectively

Variable Compensation (X3)

Compensation is the entire remuneration in the form of money, goods or pleasure given by the company to employees on performance that contributed to the company. (Gorda, 2006). Compensation indicator measured by respondents' opinions as follows.

a. Operational allowances based on the duties of employees

b. Holiday allowance given to employees

c. Incentives are given fair

d. Reward high performance

e. Recognition of work performance

Thus the high motivation that I owned an employee in the work will produce peak performance. Measured using a Likert scale with a grouping of five categories, namely: (i) $5=$ Strongly agree, (ii) $4=$ Agree, (iii) $3=$ Just agree, (iv) $2=$ disagree, (v) $1=$ Strongly agree.

Indicators of motivation as follows:

a. Decent wages

b. Security in work

c. Good cooperation relations

d. Reward high performance

e. Autonomy in the execution of work

\section{Testing Instrument Research}

\section{Results And Discussion}

Testing instrument in studies that used questionnaires needed to determine whether the measurement tools can be used or not in the data collection process. In this test the validity of the process is carried out and realibitas answers from the questionnaire. By doing the testing process this data expected results obtained with the hypothesis appropriate to the expected. 


\section{Validity test}

Test the validity of ukan sealed by correlating the score of each item with the total score of each attribute. Validity test is used to look at the accuracy and precision of a research instrument in measuring function to measure items of the statements made. The formula used in the test is the validity of Pearson Product Moment. According Sugiyono (2007: 233), C orrected item total correlation is a correlation between the total score of the item, so open to interpretation by consulting the critical value of $r$-table, if $r$ arithmetic $>r-$ critical value tables product moment the instrument is declared invalid or it can be said that the item a statement from the reflection of each variable in this study the existence of an otherwise valid research instrument (legal). The test results the validity of each item of research variables in this study each - each da pat seen in the following table.

From the table reliability test with Cronbach Alpha method can be known that the coefficient of reliability count when compared with the results of a calculation coefficient table turns $\mathrm{R}$ arithmetic $>\mathrm{R}$ table. Because the coefficient of reliability of testing outweigh the reliability coefficient table it can be concluded that the instrument proved to be reliable. From the data processing on reliability testing were obtained coefficient of reliability (Cronbach's Alpha) for the variable performance of 0,740, Education and Training variable 0, 787, motivation variable 0,787 and variable incentives 0,688 .

\section{Testing $\mathbf{H}$ ipotesis}

Berdas a Refresh on the outcome of a classic assumption test including normality test, multicollinearity test, and test heterokedastisitas showed that the estimated regression qualified classical assumptions so that the expected results will be good in analyzing the effect of independent variables on the dependent variable. Tests on the results obtained regression testing conducted simultaneously using F-test and partial test by using t-test. It can be described for more details :

\begin{tabular}{|c|c|c|c|c|c|c|c|}
\hline \multicolumn{8}{|c|}{ Hypothesis testing } \\
\hline \multirow[t]{2}{*}{ HIP } & variable & variable & \multicolumn{5}{|c|}{ Direct Effect } \\
\hline & Independent & dependent & $\mathrm{B}$ & beta & t-hit & p-value & Information \\
\hline $\mathrm{H} 1$ & $\begin{array}{l}\text { education and } \\
\text { training }\end{array}$ & $\begin{array}{c}\text { Performance } \\
\text { Power Extension }\end{array}$ & 0110 & 0042 & 2,600 & 0011 & Sig. \\
\hline $\mathrm{H} 2$ & Motivation & $\begin{array}{c}\text { Performance } \\
\text { Power Extension }\end{array}$ & 0.186 & 0062 & 2984 & 0004 & Sig. \\
\hline $\mathrm{H} 3$ & Incentive & $\begin{array}{c}\text { Performance } \\
\text { Power Extension }\end{array}$ & 0649 & 0068 & 9586 & 0000 & Sig. \\
\hline \multicolumn{8}{|c|}{$\mathrm{R}=0.890$} \\
\hline \multicolumn{3}{|c|}{ R Square $=0791$} & \multicolumn{5}{|c|}{ Ajust R square $=0784$} \\
\hline \multicolumn{3}{|c|}{$\mathrm{F}=108788$} & \multicolumn{5}{|c|}{ Sig $=0.000$} \\
\hline
\end{tabular}

Source: Data processed in 2017

Based on the results of the ANOVA analysis, the first hypothesis of research that states that the factors which consists of education and training, motivation and incentive to the energy performance $p$ enyuluh the National Family Planning Coordinating Board Makassar acceptable.

\section{Effect of Education and Training $t$ erhadap Performance Extension Workers at the National Family Planning Coordinating Board Makassar.}

Results of hypothesis testing has proven there is influence between education and training the performance of the power $\mathrm{p}$ enyuluh on Family Planning Coordinating Board onal Rice Makassar. Through calculations that have been done that have obtained value ${ }_{\mathrm{t}}$ Ti 2600 with levels of significance $(0.011<$ value $\alpha$ of 0.05 ), this means that education and training partially positive effect on $\mathrm{p}$ enyuluh energy performance at the National Family Planning Coordinating Board Makassar This means that the better the work environment, the energy performance p enyuluh the National Family Planning Coordinating Agency for the better Makassar.

The mentioned above along with a statement Khairul Akhir Lubis (2008) with the title "The Influence of training and motivation on employee performance PT. Perkebunan Nusantara IV (Persero) Medan ". That training a positive effect on improving employee performance. The result should be a balance between what is expected, it is desirable employees compared to what is given by PT. Perkebunan Nusantara IV (Persero) Branch Makassar.

Answer resp onden above can be obtained that the perception of the education and training variables can be interpreted that the respondents to rate nice. Indicators of the most dominant affect the education and training that is agreed when $t$ ice after undertaken by the committee to determine the extent of knowledge possessed by FEA after taking part in education and training, $d$ ith the holding of education and training to encourage the performance of extension workers due will directly affect the psychology of the extension 
workers and will have an impact on improving performance. And then viewed from the smallest to the indicators above which states that in implementing education $\&$ training required in the evaluation criteria.

Methods of education and training is a systematic way to provide a description widely and can condition the provision of education and training to develop the cognitive, affective and psychomotor tasks and labor to work Siswanto (2006). In fact, if $\mathrm{t}$ ice after undertaken by the committee to determine the extent of knowledge possessed by FEA after taking part in education and training and $\mathrm{d}$ ith the holding of education and training to encourage the performance of extension workers due will directly affect the psychology of the FEA and will have an impact on improving performance.

\section{Effect of Motivation Extension of the Power Performance at the National Family Planning Coordinating Board Makassar.}

Results of hypothesis testing has proven there is influence between motivation the performance of the power $\mathrm{p}$ enyuluh the National Family Planning Coordinating Board Makassar. Through calculations that have been done obtained ${ }_{t}$ value of 2,984 has a significance level of 0.004 less than the value $\alpha$ of 0.05 . This means that the motivation partially positive influence on the energy performance $\mathrm{p}$ enyuluh the National Family Planning Coordinating Board Makassar. This test is also open statistically sure that their motivational influence on the performance of energy performance $\mathrm{p}$ enyuluh the National Family Planning Coordinating Board Makassar a rtinya that there is influence between the variables of motivation on the performance of the positive and significant effect.

Greenberg (1999) Rival (2005) looked at motivation as a result of three types of beliefs of the individual, consisting of expectations of conviction that one's efforts will affect perfomance. Performance will be towards the Instrumentality, namely barupa belief that someone good performance will be given remuneration in kind. Individuals, consisting of expectations such as the belief that effort seseoran $\mathrm{g}$ will affect the performance .

Okky Setiawan (2009) with the title "Effect of Training, Compensation and Work Motivation Against Job Performance Employees Parts Industry Marketing at Perum Perhutani Unit I Central Java", the results of the analysis of multiple concluded that Training, Compensation and Work Motivation significant effect on the performance of joint, The research variables and motivation provides the most powerful influence on job performance of $61.8 \%$. Variable training, compensation and motivation to make an impact of $66.3 \%$ on job performance, while $33.7 \%$ is influenced by other variables .

Variable motivation may mean that respondents rated it good. Explained that the indicators dominant form of motivation is fourth indicator variables, ie awards to FEA achievers will push the motivation to work . By contrast, the indicator most small contribution in the formation of motivation variable is the first indicator, ie $d$ ith earn decent wages in accordance jobs will create FEA passion for the work, however, does not mean that the wages given are not in accordance with the results of work done but seen from the level of discipline and punctuality in completing the work that should be precise in completing the work for wages in accordance idak which can degrade the performance of the FEA.

The fact that the award to the extension workers who excel will encourage the spirit of the work as well as $\mathrm{d}$ ith earn decent wages in accordance jobs will create FEA passion to work in order to be able to improve the performance of power p enyuluh on Family Planning Coordinating Board of the National Makassar .

\section{Effect of Incentives Against Performance Extension Workers at the National Family Planning Coordinating Board Makassar .}

Results of testing the hypothesis has been proved there is the influence of incentives on performance of power p enyuluh on Family Planning Coordinating Board of the National Makassar. Through the results of calculations which states that the value $t_{\text {arithmetic }}$ amounted to 9586 values obtained have ti level of significance 0,000 of $\alpha$ is 0.05 , it means that the incentive partially influence positively and significantly to the performance of power p enyuluh on Family Planning Coordinating Board of the National Makassar is a rtinya that the last of its increase in variable incentive that will increase the performance of power $p$ enyuluh on Family Planning Coordinating Board of the National Makassar .

Several studies have been conducted to examine the relationship between compensation and performance. Yuniman et al (2002) conducted a study on the effect of compensation for work performance on the production employees of PT. Pancamas Elite Malang. From this research it is known that both financial compensation and non-financial compensation effect on job performance. The indicators used in describing the financial compensation is the subject of this study is salary, bonuses and benefits received by employees. Meanwhile, to describe the compensation of non financial indicators which promotions for employees, an interesting task, challenges at work, responsibility and working conditions. In the study Siagian (2005), concluded that the compensation provided to the employees of the LTO Metro has a significant influence on employee performance. The results showed the greater the compensation received, the higher the performance 
of employees. Respondents gave good value, it can be seen from the average value of 4.02. Explained that the indicators that the dominant form variable incentive is the second indicator, ie d natural incentive organizations see an old work or employment of FEA that as well as p emberian incentives to FEA whether to berd asarkan feasibility and fairness can be considered that the incentive is the basis for a the extension workers to encourage in order to carry out and finish the job so well that it will produce the desired performance. Indicators smallest contribution in the establishment of incentives is the fourth indicator variables, namely i nsentif is adjusted to bes arnya FEA needs. However, it does not mean that extension workers are given incentives vary but depending seen from the work that they accomplish.

According Sarwoto (2000: 144) regarding the incentives are one means of motivation that can be defined as a stimulant or a booster is given intentionally to employees that arise within them greater enthusiasm for $b$ erpartisipasi with the company. Added to the opinion of Marihot Old Effen in Hariandja $(2005$; 265) is Incentives is a form of direct payments associated with the performance and gain sharing and defined as profit sharing for employees due to increased produktivit ace or cost savings.

The fact that $d$ natural incentive organizations see an old work or employment of FEA these and incentives is the basis for an extension officers are to encourage in order to carry out and finish the job so well that it will produce the performance you need and the amount of incentive disusaikan needs and the work of extension workers in order to improve the performance of power $\mathrm{p}$ enyuluh on Family Planning Coordinating Board of the National Makassar. So Pember $\mathrm{i}$ an incentive is sara $\mathrm{n}$ a motivation that can meran $\mathrm{g}$ his or $\mathrm{m}$ endorong employees a $\mathrm{g}$ ar in themselves they arise se $\mathrm{m}$ angat $\mathrm{y}$ ang $\mathrm{l}$ ebih great achievement for pe $\mathrm{n}$ ingkatan performance .

With the existence of a system of incentives that good an organization is expected to improve the performance of employees. If employees get additional incentives from the organization, then he is likely to be trying to improve its performance. So Pember $\mathrm{i}$ an incentive is sara $\mathrm{n}$ a motivation that can meran $\mathrm{g}$ his or $\mathrm{m}$ endorong employees a $\mathrm{g}$ ar in themselves they arise se $\mathrm{m}$ angat $\mathrm{y}$ ang $\mathrm{l}$ ebih great achievement for pe $\mathrm{n}$ ingkatan performance.

\section{Effect of Education and Training, Motivation and Incentive Against Performance Power educator at Family Planning Coordinating Board of the National Makassar .}

Based on the multiple linear regression equation mentioned above, it can diinterpresentasikan that the constant $\left(b_{0}\right)$ obtained from the value of 0238 which states that the magnitude of the performance of power $p$ enyuluh on Family Planning Coordinating Board of the National Makassar is comprised of Education and Training, Motivation and Incentive Power $p$ enyuluh on National Family Planning Coordinating Board Makassar .

The amount of the contribution of variable educational and work environment, employee incentives and job placement to the performance of power $\mathrm{p}$ enyuluh on Family Planning Coordinating Board of the National Makassar and can be seen from the determination coefficient is 0,781 or by 78.1 percent.

Of the three variables that affect performance dominant power $\mathrm{p}$ enyuluh on Family Planning Coordinating Board of the National Makassar is variable incentives with tinkat significance of 0.000 which is smaller value than the value of 0.05 . It can be seen fact that $d$ natural incentive organizations see an old work or employment of FEA these and incentives is the basis for an extension officers are to encourage in order to carry out and finish the job so well that it will produce the performance you need and the amount of incentive disusaikan with the needs and the work of the extension officers in order to improve the performance of power $p$ enyuluh on Family Planning Coordinating Board of the National Makassar. So Pember i an incentive is sara $\mathrm{n}$ a motivation that can meran $\mathrm{g}$ his or m endorong employees a $\mathrm{g}$ ar in themselves they arise se $\mathrm{m}$ angat $\mathrm{y}$ ang $1 \mathrm{ebih}$ great achievement for pe $\mathrm{n}$ ingkatan performance .

\section{Conclusions And Suggestions}

Based on the analysis and discussion of the results of the study, the researcher mensimpulkan as follows: Based on the analysis and discussion of the results of the study, the researcher mensimpulkan as follows:

1. The results showed that the variables of education and training, motivation and incentives simultaneously significant positive effect on the performance of power p enyuluh on Family Planning Coordinating Board of the National Makassar .

2. Factors most dominant influence on the performance of power p enyuluh on Family Planning Coordinating Board of the National Makassar is an incentive. By providing incentives to employees on a regular basis then it can help take into fast eds elesai an inside job because the more diligent, creative and can create new things $d$ a lam completed tuags and tanggng he replied.

3. From the calculation results of multiple regression determination coefficient $R^{2}$ (R Square) shows that all independent variables simultaneously positive and significant impact. While the correlation coefficient indicates a very strong relationship between the independent variables with the dependent variable. 
4. Simultaneously and partially work motivation, incentives and organizational culture have a significant effect on the performance of power $\mathrm{p}$ enyuluh on Family Planning Coordinating Board of the National Makassar .

\section{Suggestion}

Based on the conclusions drawn then the advice that can be given is as follows:

1. The National Family Planning Coordinating Board Makassar constantly improving the performance of extension workers through the conduct education and training, motivation and incentives.

2. Always hold trainings in order to improve the performance of extension workers from doing workshops, training and competency training so as to realize the performance improvements FEA.

3. Incentives should be continuous so as to further boost morale and $\mathrm{k}$ in Gov on power p enyuluh on Family Planning Coordinating Board of the National Makassar.

4. Employee motivation should be owned by every performance power p enyuluh on Family Planning Coordinating Board of the National Makassar in order to create maximum performance and can improve the performance of employees.

\section{Bibliography}

[1]. Anwar, 2000. Human Resource Management. Rineka Cipta, Jakarta.

[2]. Armstrong, Michael.2009. Armstrong's Handbook of Human Resource Management Practice. London: Kogan Page

[3]. Badriah Djula 2012. Effect of Incentives Against Employee Performance Plaza Amanda Jaya. (Thesis).

[4]. Dessler, Gary, 2001. Human Resource Management. Translation, Seventh Edition, Erland, Jakarta. Gibson Ivancevich, 2003. Organizational Behavior, Structure and Process of Micro, publisher, Jakarta

[5]. Gomes, Faustino Cardoso, 2003, Human Resource Management, Publisher Andi, Yogyakarta

[6]. Harsono (2009). Effect of Education and Training, Job Satisfaction Against Employee Performance With Organizational Commitment As an intervening variable in the Legislative Council Secretariat Karanganyar (Thesis).

[7]. Handoko, T. Hani. 2000. Personnel Management and Human Resources ,. Edition 2.Yogyakarta: BPFE

[8]. Hasibuan. 2005. Human Resource Management. Jakarta: CV. Haji Masagung.

[9]. Hasibuan, Malay S.P. 2002. Human Resource Management. Earth Literacy. Jakarta

[10]. Handoko, T. Hani, 2002. Personnel Management and Human Resources. Publisher BPFE, Yogyakarta.

[11]. Hasibuan, Malay. 2001. Human Resource Management: The Basics, Understanding, and Problems.

[12]. Jakarta: PT. Toko Gunung Agung,

[13]. Koesmono (2007). Influence of Organizational Culture Motivation And Job Satisfaction And Performance Sub-Sector Employees Medium Sized Wood Processing Industry In East Java (Journal).

[14]. Manulang, M, 2002, Personnel Management, Balai Pustaka, Jakarta

[15]. Mangkunagara, (2002), Human Resource Management, PT. Teens Rosda paper, Bandung

[16]. Mangkunagara AP. 2005. Human Resource Management. Bandung: Rosdakarya

[17]. Mangkunagara AP. 2005. Human Resource Management. Bandung: Rosdakarya

[18]. Mathis Robert L \& Jackon H. 2002. Human Resource Management. Jakarta: Four Salemba

[19]. Mangkunagara, Anwar Prabu, 2007. Performance Evaluation of Human Resources. Refika Aditama, Bandung

[20]. Mangkunagara, (2002), Human Resource Management, PT. Teens Rosda paper, Bandung

[21]. Mustafa (2007). PengaruhPendidikan and Performance Against Government Officials Training Village (Journal)

[22]. Panggabean, Pearl S, 2002. Human Resource Management. Jakarta: Ghalia Indonesia Indonesian Government Regulation No. 101 of 2000 on Education and Training Position Pegawa Ivan Aries and Imam Ghozali 2006

[23]. Robbins, Stephen P., (2001). Organizational Behavior, 9th Ed. Upper Saddle River New Jersey 07458: Prentice Hall International.

[24]. Sastradipoera, Komaruddin. 2002. Human Resources management functions Operative An Approach I. Publisher Edition KappaSigma: Bandung

[25]. Setyanto, R., 2002. Employee Assessment. Publisher Harvarindo, Jakarta.

[26]. Sedarmayanti, 2009. Human Resources and Work Productivity. Mandar Maju, Bandung

[27]. Simamora. 2001. Human Resource Management. 3rd edition. STIE YKPN. Yogyakarta.

[28]. Soedjono. 2005. Systems and Work Procedures. Earth Literacy. Jakarta

[29]. Soekidjo. 2003. Education and health behaviors, Jakarta: Rinka Reserved

[30]. Sugiyono, 2008. Business Research Methods. Moulds twelfth, 2008. Publisher Alfabeta, Bandung

[31]. Shah. 2002. The specialty of Aceh in track history, Jakarta: Executive Board of the Al-Jami'iyatul Washliyah

[32]. Sulistiyani. Ambar Q. And Rosidah. 2003. Human Resource Management. Yogyakarta: Graha Science.

[33]. Siswanto. 2006. Disbursement DanaKompensasi in Bekasi RawanKeributan, inhttp://www.tempointeraktif.com/, Tuesday, October $18,2009$.

[34]. Sukamti (2008). Effect of Education and Training, Human Resources Empowerment, Motivation, Communication and Work Experience on Employee Performance Secretariat of the Regional Representatives Council Wonogiri (Thesis).

[35]. Tjutju Yuniarsih and Suwatno. 2008. Human Resource Management. Bandung: Alfabeta Law of the Republic of Indonesia number 43 of 1999 on Employment

[36]. Veithzal Rival (2009). Human Resource Management for the Company. Jakarta: RajaGrafindo Persada.

[37]. Vendy Martcahyo Aries. (2010). Effect of Job Training, Social Security and Employee Performance Incentive Against the Production Department PT. Fumira Semarang.

[38]. Wursanto, 2004. Personnel Management, Fourth Moulds, Publisher Kenasiar, Jakarta 